\title{
Analisis butir soal penilaian akhir semester muatan pembelajaran IPS \\ di kelas 5: Ditinjau dari kompetensi abad 21
}

\author{
${ }^{1}$ Ranti Agustina, ${ }^{2}$ Tin Rustini, ${ }^{3}$ Yona Wahyuningsih \\ 1 $\underline{\text { rantiagustina@upi.edu }}$ \\ 1,2,3PGSD, Pedagogik, Universitas Pendidikan Indonesia Kampus Cibiru
}

\begin{abstract}
ABSTRAK
Penelitian ini dilatarbelakangi dengan kesesuaian soal Penilaian Akhir Semester yang masih dipertanyakan, karena pembuatan naskah soal tidak dilaksanakan oleh guru yang bersangkutan dan tidak dilakukan kegiatan analisis butir soal sebelum diujikan. Tujuan dari penelitian ini untuk mendeskripsikan hasil analisis kesesuaian soal Penilaian Akhir Semester mata pelajaran IPS kelas 5 dengan kompetensi dasar dan materi IPS, juga mendeskripsikan hasil analisis ditinjau dari kompetensi abad 21 pada aspek kompetensi berpikir kritis dan komunikasi tertulis. Metode yang digunakan deskriptif kualitatif dengan desain analisis isi. Sumber data penelitian adalah naskah soal Penilaian Akhir Semester mata pelajaran IPS kelas 5 semester ganjil tahun ajaran 2020/2021. Teknik pengumpulan data menggunakan dokumentasi, observasi wacana, dan wawancara. Teknik analisis data yang digunakan yaitu analisis data kualitatif menurut Miles dan Huberman. Hasil penelitian menunjukkan bahwa naskah Penilaian Akhir Semester mata pelajaran IPS kelas 5 semester ganjil tahun ajaran 2020/2021 tidak semuanya memiliki kesesuaian dengan kompetensi dasar dan materi IPS. Keterampilan abad 21 pada kompetensi berpikir kritis dan komunikasi tertulis dalam butir soal tidak sama rata untuk setiap indikator. Pada keterampilan berpikir kritis indikator yang termuat paling tinggi yaitu menyimpulkan (inference), sedangkan pada keterampilan komunikasi tertulis indikator bahasa yang memiliki muatan paling tinggi.
\end{abstract}

Kata kunci: analisis soal; kompetensi abad 21; berpikir kritis; komunikasi tertulis

\section{Analysis of end semester assessment questions for social science subjects of $5^{\text {th }}$ grade students: Reviewing from 21st century competency}

\begin{abstract}
This research is motivated by the suitability of end semester asessment question which are still questionable, because the making of the end semester asessment question is not carried out by the teacher concerned and no item analysis activities are carried out before being tested. This research aims to describe the result of the analysis suitability social sciences subjects in class 5 with basic competencies and social sciences material, also to describe the results of the analysis in terms of 21st century competencies in the aspects of critical thinking competence and written communication. The research method is descriptive qualitative with content analysis design. The data source of reasearch data is the end semester asessment question text for class 5 social studies subject in the odd semester of the 2020/2021 school year. The data collection technique used documentation, discourse observasion and interviews. The data analysis technique used is qualitative data analysis according to Miles and Huberman. The result showed that the end semester asessment question text for class 5 social studies subject in the odd semester of the 2020/2021 school year did not all have conformity with basic competencies and social sciences material. The 21st century skills on critical thinking competence and written communication competence in items are not the same for each indicator. In critical
\end{abstract}


thinking skills the indicator that contains the highest content is inference, while in written communication skills the indicator of language has the highest content.

Keywords: question analysis; 21st century competencies; critical thinking; written communication

Received: Sept 30th, $2021 \quad$ Reviewed: Oct 5 $5^{\text {th }}, 2021 \quad$ Accepted: Nov 3 ${ }^{\text {rd }}, 2021 \quad$ Published: Jan 31 $31^{\text {st }}, 2022$

\section{PENDAHULUAN}

Pendidikan sekarang ini didesain untuk mempersiapkan peserta didik supaya dapat bertahan hidup, maksudnya bukan hanya mempersiapkan masa depan tetapi peserta didik dituntut untuk selalu siap dalam keadaan apapun. Sejalan dengan pendapat Uno bahwa tujuan penting pendidikan yaitu kemampuan mental yang dapat dikembangkan sehingga orang dapat belajar, dan terfokus pada proses belajarnya bukan pada hasil belajarnya. Sehingga sumber daya yang dapat hidup dan bersaing di dunia global yaitu manusia yang unggul (Uno \& Lamatenggono, 2016).

Tujuan dari pendidikan IPS juga sejalan dengan tujuan pendidikan nasional, menurut Effendi tujuan pendidikan IPS tingkat Sekolah Dasar difokuskan untuk mengembangkan pengetahuan serta keterampilan peserta didik dalam kehidupan sehari-hari yang dimulai dari dasar". Sebagai contoh materi sejarah sebagai pemahaman peserta didik terhadap perkembangan masyarakat Indonesia dari dahulu sampai sekarang, sehingga diharapkan peserta didik dapat bangga menjadi warga negara Indonesia (Effendi, 2012).

Proses pendidikan bisa didapatkan salah satunya dengan cara mengikuti proses pembelajaran dalam suatu jenjang pendidikan. Dalam pelaksanaannya kegiatan pembelajaran tentunya harus selalu mengikuti perkembangan dan melakukan revisi, terutama terhadap kelemahan dan kekurangan yang mucul ketika proses pembelajaran berlangsung juga pada capaian belajar peserta didik. Untuk mengetahui sejauh mana peserta didik dapat memahami dan menerima materi yang disampaikan, juga untuk mengetahui tingkat ketercapaian tujuan pembelajaran maka dapat dilakukan kegiatan evaluasi. Salah satu bentuk evaluasi yang dapat digunakan di sekolah yaitu tes PAS (Penilaian Akhir Semester), kegiatan ini dilakukan pada akhir pembelajaran dalam satu semester. Bentuk soal yang biasanya digunakan dalam kegiatan evaluasi ini yaitu pilihan ganda dengan uraian, tentunya dalam penyusunan soal dalam bentuk apapun harus berorientasi pada 
pengembangan kompetensi, berpusat pada peserta didik dan penilaian berbasis proses juga hasil belajar. Maka dari itu kualitas dari butir soal kegiatan evaluasi pembelajaran sangat penting dan harus diperhatikan.

Kompetensi dan pemahaman guru dalam merumuskan butir soal menjadi salah satu faktor pendukung dalam merumuskan butir soal yang baik. Faktanya masih banyak guru yang belum dapat merumuskan butir soal sesuai dengan kaidah penyusunannya, terutama dalam mata pelajaran IPS. Dalam penelitian yang dilakukan Valen, ditemukan bahwa terdapat guru yang belum memahami dan mengetahui kaidah dalam penyusunan butir soal. Pada penelitian tersebut juga terbukti bahwa keterampilan dan pemahaman guru yang kurang maksimal dalam menyusun soal Mid semester mata pelajaran IPS dari ditemukannya lebih banyak butir soal LOT dibandingkan dengan soal HOTS, sedangkan urgensi dari berpikir tingkat tinggi sekarang ini sangat penting karena merupakan bagian dari kompetensi yang dibutuhkan peserta didik yaitu pada kompetensi abad ke-21 (Valen, 2020).

Fenomena yang terjadi ketika kompetensi guru masih rendah dalam memahami kaidah penyusunan soal, tentunya akan berdampak pada kualitas butir soal yang akan diujikan. Sementara itu, di sisi lain guru harus dapat mengembangkan segala ranah yang terdapat dalam diri peserta didik termasuk berpikir kritis (Jupriyanto, 2018). Untuk menanggulangi terjadinya butir soal yang tidak berkualitas digunakan dalam kegiatan evaluasi, tentunya kegiatan analisis butir soal sangat diperlukan sebelum naskah soal dipergunakan. Seperti pada penelitian Kurniawati yang menyimpulkan bahwa "hasil analisis butir soal naskah soal IPS memenuhi keterampilan berpikir kritis karena memiliki validitas isi dengan expert judgment" (Kurniawati, 2021). Selain itu pada penelitian yang dilakukan Santika, dari hasil analisis butir soal tidak memuat soal HOTS sehingga tidak dapat dipergunakan sebagai persiapan dalam penerapan Kurikulum 2013 (Santika, 2019). Dari hasil penelitian di atas, dapat disimpulkan bahwa kegiatan analisis butir soal dapat membantu untuk mengetahui kelayakan dari setiap butir soal dan dapat mengetahui kesesuaian muatan kompetensi butir soal yang terkandung. Hal ini sesuai dengan pendapat Zuriyanti, yakni "manfaat dari analisis butir soal yaitu menemukan soal cacat dan soal yang tidak berfungsi dengan baik, meningkatkan kualitas butir soal, meningkatkan validitas soal dan reliabilitas, merevisi soal yang tidak sesuai dengan materi yang diajarkan" (Fitrianawati, 2015). 
Kegiatan analisis butir soal tentunya akan sangat baik jika indikator dari analisis yang digunakannya juga berkualitas dan memuat keterampilanketerampilan yang dibutuhkan saat ini. Dengan demikian akan mengukur naskah soal yang digunakan apakah sesuai dan mengikuti perkembangan zaman atau tidak. Keterampilan yang sangat penting dan dibutuhkan sekarang ini yaitu memuat kompetensi abad ke-21 atau yang sering disebut dengan kompetensi 4C. Kompetensi-kompetensi ini dirancang oleh Kemendikbud di sekolah dengan menanamkan pendidikan karakter, karena dengan menumbuhkan karakter siswa dapat berpikir kritis, kreatif, mampu berkomunikasi, dan berkolaborasi di abad 21 . Hal tersebut sesuai dengan empat kompetensi yang harus dimiliki peserta didik menurut Kemendikbud yaitu "Critical Thinking and Problem Solving (berpikir kritis dan menyelesaikan masalah), Creativity (kreativitas), Communication Skills (Kemampuan berkomunikas), dan Ability to Work Collaboratuvely (kemampuan untuk bekerja sama)" (Pengelola Web Kemendikbud, 2017). Maka dari itu, jika naskah soal yang dibuat untuk kegiatan evaluasi mengandung unsur pengembangan keterampilan-keterampilan tersebut maka dirasa dapat membuat peserta didik menjadi berpikir kritis, kreatif, inovatif, dapat memecahkan masalah, mampu beradaptasi dengan lingkungan dan teknologi informasi, mampu mengambil keputusan dan berkarakter kuat juga positif.

Dalam pembuatan naskah soal tentunya harus memperhatikan materi, konstruksi dan bahasa yang dipergunakan. Kolaborasi dari ketiga hal tersebut akan membuat komunikasi tertulis pada naskah soal tersampaikan dengan baik kepada peserta didik, sehingga soal akan mudah dipahami dan jawaban dapat dikembangkan dengan baik oleh peserta didik. Naskah soal tentunya harus memiliki tantangan untuk peserta didik dalam pengerjaannya, naskah soal yang rutin akan membuat anak merasa bosan dan tidak berpikir secara mendalam untuk penyelesaiannya. Isbandiyah dan Sanusi menyatakan "siswa dapat berpikir secara luas dan mendalam mengenai materi yang sudah dipelajari selama proses pembelajaran dikarenakan dorongan dari penggunaan soal HOTS” (Isbandiyah \& Sanusi, 2019). Berpikir tingkat tinggi atau berpikir kritis merupakan bagian dari kompetensi abad ke-21, sehingga aspek tersebut juga dapat dijadikan indikator acuan dalam pelaksanaan analisis butir soal sebagaimana pendapat Priyanti dalam kegiatan seminar nasional mengenai urgensi penilaian pembelajaran abad ke-21, disusun untuk mengembangkan dan mengukur capaian dari proses belajar peserta 
didik dalam kompetensi pengetahuan beberapa diantaranya dalam indikator kompetensi berpikir kritis dan komunikasi (Priyanti, 2013).

Mata pelajaran IPS merupakan ilmu yang kajiannya difokuskan pada manusia dan secara tidak langsung akan membantu pemikiran peserta didik terhadap orientasi kehidupan di masa depan. Menurut Gross, dkk., "Social Studies are central in the proper general education of our young people, focusing as it does on humankind, on our institutions, and our relationships with nature and one another" (Mutiani, 2017). Pendidikan IPS terfokus dalam pendidikan umum untuk menyiapkan generasi muda, dengan fokus kajian seperti halnya pada manusia, pada institusi kami, dan hubungan kita dengan alam dan satu sama lain. Dengan demikian karena IPS membuat pemikiran yang berorientasi pada masa depan, tentunya penggunaan soal evaluasi pada mata pelajaran IPS harus dapat mengandung dan memenuhi kompetensi keterampilan abad ke-21 yang ditanamkan sejak dini pada jenjang sekolah dasar.

Namun kenyataannya di lapangan, soal-soal mata pelajaran IPS yang dipergunakan masih belum memenuhi kaidah penulisan soal yang baik da belum mencangkup kompetensi abad ke-21. Dalam penelitian yang dilakukan pada naskah soal PAT kelas 5 SD oleh Yuniar, soal yang disusun belum memenuhi prinsip pengembangan soal abad ke-21 dikarenakan soal yang dihasilkan tidak HOTS (Yuniar, 2020). Selain itu penelitian yang dilakukan oleh Marliana menemukan soal tes IPS yang masih minim memiliki indikator HOTS (Mutiani, 2017). Pada penelitian Wandi dari analisis butir soal yang dilakukan menggunakan indikator HOTS atau berpikir tingkat tinggi pada soal-soal tes IPS kelas 5 tidak semua soal memuat indikator tersebut (Wandi, 2020).

Dalam merumuskan butir soal harus dilakukan secara baik dan benar sehingga dapat menghasilkan butir soal yang dapat mengukur secara objektif dan akurat, maka soal sebagai alat ukur yang digunakan dalam tes harus berkualitas. Sehingga kegiatan analisis butir soal dapat menjadi sarana yang dilakukan untuk pengukuran kualitas dari naskah soal. Berdasarkan hasil observasi dan wawancara di lapangan menemukan bahwa SDN Cibiru 06 belum melaksanakan analisis butir soal dengan baik. Sebagaimana penjelasan dari salah satu guru di sekolah tersbebut kegiatan analisis butir soal tidak dilakukan sebelum diujikan pada peserta didik. Sedangkan dapat dikerahui bahwa tujuan dari analisis butir soal adalah menelaah dari butir-butir soal sebelum digunakan agar dapat diketahui kekurangannya dan direvisi. Selain itu materi pada soal yang diujikan dikhawatirkan tidak sesuai dengan 
materi yang diberikan selama pembelajaran, karena pembuatan soal tidak dilakukan secara langsung oleh guru tetapi dibuat oleh pihak Gugus. Oleh karena itu kualitas dari butir soal pada naskah soal masih dipertanyakan.

Dari uraian permasalahan diatas, peneliti termotivasi melakukan penelitian sebagai solusi dengan melakukan analisis butir soal pada naskah soal. Dengan berfokus pada kompetensi abad ke-21 yaitu 4C, dari empat indikator kompetensi tersebut dipilih dua indikator untuk difokuskan yaitu pada indikator berpikir kritis (Critical Thinking) dan indikator komunikasi tertulis pada soal (Communication Skills). Dengan judul penelitian "Analisis Butir Soal Penilaian Akhir Semester Mata Pelajaran IPS di Kelas 5 ditinjau dari Kompetensi Abad 21", memiliki rumusan masalah yaitu: (1) Bagaimana kesesuaian butir soal Penilaian Akhir Semester mata pelajaran IPS kelas 5 pada tahun ajaran 2020/2021 dengan Kompetensi Dasar dan Konten IPS di SD?; (2) Bagaimana hasil analisis keterampilan berpikir kritis (Critical Thinking) pada butir soal Penilaian Akhir Semester mata pelajaran IPS kelas 5 SD pada tahun ajaran 2020/2021?; (3) Bagaimana hasil analisis keterampilan komunikasi tertulis (Communication Skills) pada butir soal Penilaian Akhir Semester mata pelajaran IPS kelas 5 SD pada tahun ajaran 2020/2021?.

\section{METODE PENELITIAN}

Dalam penelitian analisis butir soal Penilaian Akhir Semester ini menggunakan metode deskriptif dengan pendekatan kualitatif. Menurut Sukardi, penelitian desktiptif dilakukan bertujuan untuk menggambarkan secara sistematis fakta dan karakteristik objek atau subjek yang diteliti secara tepat (Sukardi, 2016). Tujuan pada penelitian kualitatif ini yaitu ingin mengetahui secara mendalam mengenai analisis butir soal Penilaian Akhir Semester mata pelajaran IPS di kelas 5 SD ditinjau dari kompetensi abad 21, dari empat kompetensi abad ke-21 yang sering disebut 4C penelitian ini berkofus pada dua indikator kompetensi yaitu keterampilan berpikir kritis (critical thinking) dan keterampilan komunikasi (communication skill) tertulis yang terkandung dalam naskah soal.

Untuk pendekatan yang digunakan pada penelitian ini yaitu penelitian kualitatif. Penelitian kualitatif berisikan deskriptif kata-kata tertulis atau lisan dari hasil pengamatan, menurut Moleong penelitian kualitatif adalah penelitian yang menghasilkan prosedur analisis yang tidak menggunakan prosedur analisis statistik atau cara kuantitatif lainnya (Moleong, 2017). Penelitian deskriptif kualitatif menurut Mukhtar merupakan penelitian yang berdasarkan logika keilmuan, 
prosedur dan metodologi juga teoritis yang sesuai dengan bidang keilmuan. Penelitian ini juga mengungkap secara objektif sebuah fakta empiris (Mukhtar, 2013).

Desain yang peneliti pilih dalam penelitian ini yaitu analisis isi (Content Analysis). Analisis isi merupakan sebuah metode untuk memaknai teks atau konten, menurut Mukhtar penelitian analisis isi banyak digunakan pada penerbitan media cetak seperti koran, buku juga majalah. Selain itu juga digunakan untuk menganalisis undang-undang, peraturan pemerintah laporan, naskah dan lain-lain (Mukhtar, 2013). Penggunaan analisis isi ini disesuaikan dengan alasan peneliti melakukan penelitian ini, karena peneliti ingin meneliti mengenai analisis butir soal Penilaian Akhir Semester mata pelajaran IPS di kelas 5 SD ditinjau dari dua kompetensi abad ke-21 yaitu kompetensi berpikir kritis dan komunikasi tertulis yang disajikan dalam bentuk deskriptif kualitatif.

Objek utama penelitian yang digunakan dalam penelitian ini yaitu, naskah soal Penilaian Akhir Tahun (PAS) semester ganjil pada mata pelajaran IPS kelas V tahun ajaran 2020/2021. Naskah soal tersebut didapatkan dari salah satu sekolah dasar di Kabupaten Bandung, yaitu di SDN Cibiru 06 Kabupaten Bandung yang beralamatkan di Jl. Pendidikan No. 12 Kp. Cibiru Hilir, CIBIRU HILIR, Kec. Cileunyi, Kab. Bandung Prov. Jawa Barat. Jenis satuan SDN Cibiru 06 dengan akreditas A. Sekolah dasar ini memiliki peserta didik kelas 1 sampai dengan kelas 6 yang berjumlah 461 orang, dengan jumlah guru 19 terdiri dari 9 PNS dan 10 Honorer juga 1 tenaga kependidikan.

Analisis data merupakan proses mencari, mengolah, mengelompokkan dan menyusun data yang didapatkan dari berbagai sumber melalui wawancara, catatan lapangan, dokumentasi, dan sumber lain yang pada akhirnya akan dibuat kesimpulan dari berbagai temuan di lapangan. Dalam menentukan analisis data pada suatu penelitian, pendekatan yang digunakan pada penelitian tersebut menjadi acuannya. Pendekatan dalam penelitian ini yaitu deskriptif kualitatif, dan peneliti memilih menggunakan analisis data model Miles dan Huberman.

Analisis data model Miles dan Huberman dalam Mukhtar mengemukakan model data ini flow model analysis (berlangsung mengalir). Pada pemaparannya terdapat empat aktivitas analisis yang dilakukan, diantaranya yaitu pengumpulan data, reduksi data, display data dan terakhiri verifikasi data. Langkah-langkah analisis data pada model Miles dan Huberman sebagai berikut: (1) Pengumpulan data atau (Data Collection) merupakan langkah peneliti dalam mengumpulkan data 
yang dibutuhkan. Dalam penelitian ini, peneliti mengumpulkan data via daring dan luring. Peneliti memperoleh data dari hasil dokumentasi pada naskah soal Penilaian Akhir Semester tahun ajaran 2020/2021, selanjutnya melalui observasi wacana pada naskan soal Penilaian Akhir Semester mata pelajaran IPS kelas 5; (2) Reduksi Data atau (Data Reduction) memiliki arti menyeleksi, merangkum, menyederhanakan, memilih hal-hal pokok, memfokuskan analisis data supaya menjadi lebih jelas dengan membuang data yang tidak penting. Data yang sudah direduksi akan membuat gambaran menjadi lebih jelas, tajam, ringkas dan terfokus sehingga akan memudahkan peneliti. Langkah pertama dari reduksi data pada penelitian ini yaitu, melakukan tingkat kesesuaian soal dengan Kompetensi Dasar dan Materi IPS untuk mengetahui kesesuaian materi pada naskah soal. Selanjutnya menganalisis tingkat kritis butir soal dengan mengkategorikan setiap butir soal Penilaian Akhir Semester mata pelajaran IPS kelas 5 dengan instrumen yang sudah dibuat. Setelah itu menganalisis setiap butir soal untuk mengecek keterampilan komunikasi tertulis berdasarkan materi, konstuksi dan bahasa pada butir soal. Terakhir peneliti menyamakan presepsi hasil diskusi dengan guru berupa bukti wawancara tentang kemampuan berpikir kritis dan komunikasi tertulis soal Penilaian Akhir Semester; (3) Display Data atau penyajian data merupakan langkah dalam menyusun informasi sebagai upaya mendapatkan kesimpulan. Pada penelitian ini, peneliti menyajikan data dari pokok permasalahan munculnya kompetensi abad 21 pada indikator keterampilan berpikir kritis (critical thinking) dan keterampilan komunikasi (communication skill) tertulis pada soal Penilaian Akhir Semester tahun ajaran 2020/2021. Data pada penelitian deskriptif kualitatif ini, akan disajikan dalam bentuk tabel dan teks narasi (deskripsi); (4) Verifikasi atau menarik kesimpulan merupakan langkah akhir dalam melakukan analisis data. Pada langkah ini, harus benar-benar memperhatikan tahap reduksi data dan penyajian data supaya kesimpulan dari penelitian dapat sesuai dengan rumusan masalah yang ada pada penelitian. Kesimpulan yang dibuat harus dapat dipahami dan dalam bentuk pernyataan yang singkat (Mukhtar, 2013).

\section{HASIL DAN PEMBAHASAN}

Dari kegiatan wawancara yang sudah dilakukan ditemukan bahwa pemahaman guru mengenai keterampilan abad ke-21 masih minim. Pendapat guru yang bersangkutan mengenai pengkategorian butir soal selama wawancara yaitu: 1) Aspek memberikan penjelasan sederhana (elementary clasification) sebanyak 25 
butir soal; 2) Aspek membangun keterampilan dasar (basic support) sebanyak 17 butir soal; 3) Aspek menyimpulkan (inference) sebanyak 14 butir soal; 4) Aspek membuat penjelasan lanjut (advanced clarification) sebanyak 3 butir soal; 5) Aspek strategi dan taktik (strategies and tactics) sebanyak 2 butir soal. Sedangkan ketika guru diminta untuk mengkategorikan soal-soal sesuai muatan keterampilan komunikasi tertulisnya, guru tersebut berpendapat bahwa seluruh butir soal memuat indikator materi, konstruksi, bahasa dan seluruh sub indikator dalam keterampilan tersebut.

Dari hasil analisis yang dituangkan pada temuan dan pembahasan, persebaran muatan kompetensi dasar dan konsep IPS belum sama rata. Naskah soal didominasi oleh butir soal bermuatan kompetensi dasar 3.2 mengenai interaksi sosial, selain itu kesesuaian butir soal dengan kompetensi dasar dan materi IPS tidak termuat dalam keseluruhan butir soal sehingga hal tersebut menjadi salah satu penyebab dari persebaran muatan kompetensi dasar dan materi IPS tidak merata. Dari keseluruhan 35 butir soal terdapat 33 soal yang memiliki kesesuaian soal dengan kompetensi dasar dan materi IPS sedangkan 2 soal tidak sesuai, menurut Nuriyah kegiatan evaluasi yaitu suatu usaha untuk mendapatkan informasi perolehan peserta didik selama proses pembelajaran dalam aspek pengetahuan, konsep, sikap, nilai, dan keterampilan proses. Sehingga jika terdapat buir soal yang tidak sesuai dengan bahasan materi yang diberikan pada peserta didik, maka usaha guru dalam mendapatkan informasi perolehan pemahaman peserta didik selama proses pembelajaran akan terhambat (Nuriyah, 2014). Hal yang penting ketika merumuskan naskah soal yaitu perencanaan kegiatan evaluasi, dengan demikian guru dapat menganalisis kebutuhan yang akan dilakukan dari kegiatan evaluasi oleh butir soal tersebut yang disesuaikan dengan tujuan, kompetensi dan hasil belajar yang dirancang melalui kisi-kisi (Arifin, 2016).

Untuk keterampilan abad ke-21 pada aspek keterampilan berpikir kritis (critical thinking) naskah soal, dapat dilihat dari akumulasi jumlah soal yang termuat dalam persentase berikut:

Tabel 1. Penggolongan soal bermuatan keterampilan berpikir kritis

\begin{tabular}{|c|c|c|c|}
\hline $\begin{array}{c}\text { Keterampilan Berpikir } \\
\text { Kritis }\end{array}$ & No Soal & Persentase & Kategori \\
\hline $\begin{array}{l}\text { Memberikan penjelasan } \\
\text { sederhana (Elementary } \\
\text { Clasification) }\end{array}$ & $\begin{array}{l}2,4,5,7,8,10,11,13,15, \\
17,19,20,23,25,28,29, \\
30,31,33,34,35 .\end{array}$ & $60 \%$ & Sedang \\
\hline Membangun & $4,5,8,10,11,13,14,17$ & $48.5 \%$ & Sedang \\
\hline
\end{tabular}


keterampilan dasar (Basic

Support)

Menyimpulkan

(Inference)

Membuat penjelasan

lanjut (Advanced

Clarification)
$19,20,23,29,30,31,33$,

34,35 .

$2,4,5,7,8,10,11,12,13$,

$14,15,17,19,22,23,24$,

$25,26,28,30,31,33,34$,

35 .

$4,5,7,8,17,19,33,34$ 35 .
$68.5 \% \quad$ Banyak

$25.7 \% \quad$ Sedikit

Berdasarkan tabel diatas untuk setiap aspek indikator yang digunakan dalam analisis memiliki perbandingan jumlah soal yang jauh. Sehingga dapat disimpulkan bahwa muatan keterampilan berpikir kritis butir soal dari lima aspek yang digunakan tidak merata. Pada aspek memberikan penjelasan sederhana (elementary clasification) meliputi memfokuskan pertanyaan, mengalaisis argumen, bertanya dan menjawab pertanyaan klasifikasi terdapat 21 soal. Membangun keterampilan dasar (basic support) meliputi mempertimbangkan keterpercayaan sumber, mengobservasi dan mempertimbangkan hasil observasi terdapat terdapat 17 butir soal. Menyimpulkan (inference) meliputi membuat dan mempertimbangkan hasil deduksi, membuat dan mempertimbangkan hasil induksi, membuat dan mempertimbangkan hasil keputusan terdapat 24 butir soal. Membuat penjelasan lanjut (advanced clarification) meliputi mengidentifikasi istilah dan mempertimbangkan definisi, mengidentifikasi asumsi terdapat 9 butir soal. Strategi dan taktik (straregies and tactics) meliputi menentukan tindakan, berinteraksi dengan orang lain terdapat 20 butir soal.

Begitu juga keterampilan abad ke-21 dalam aspek keterampilan komunikasi tertulis soal (communication skills) pada naskah soal, memiliki muatan butir soal yang tidak merata antar setiap indikator. Maksudnya terdapat indikator yang termuat banyak dalam butir soal dan sebaliknya. Berikut penggolongan soal keterampilan komunikasi (Communication Skills) tertulis pada naskah soal Penilaian Akhir Semester dari hasil analisis:

Tabel 2. Penggolongan soal bermuatan keterampilan komunikasi tertulis

\begin{tabular}{llc}
\hline \multicolumn{1}{c}{$\begin{array}{c}\text { Aspek } \\
\text { Indikator }\end{array}$} & \multicolumn{1}{c}{ Pilihan Ganda } \\
\hline Materi & \multicolumn{1}{c}{ No Soal } & $\begin{array}{c}\text { Jumlah } \\
\text { Soal }\end{array}$ \\
Konstruksi & $2,4,8,9,10,12,14,15,17,20$ & 10 \\
Bahasa & $2,4,5,10,12,13,14,15,16,18,20$ & 15 \\
\hline
\end{tabular}




\begin{tabular}{llc}
\hline \multicolumn{1}{c}{$\begin{array}{c}\text { Aspek } \\
\text { Indikator }\end{array}$} & \multicolumn{1}{c}{ Uraian } \\
\hline Materi & \multicolumn{1}{c}{ No Soal } & $\begin{array}{c}\text { Jumlah } \\
\text { Soal }\end{array}$ \\
Konstruksi & $22,23,24,25,29,30,31,33,34$ & 9 \\
Bahasa & $21,28,31,32,33,34,35$ & 7 \\
& 33,34 & 14 \\
\hline
\end{tabular}

Dari tabel di atas terlihat ketiga indikator yang dimuat dalam keterampilan komunikasi tertulis soal yaitu indikator materi sebanyak 19 soal, indikator konstruksi 22 soal dan indikator bahasa 25 soal. Penelitian ini memiliki hasil yang sama dengan penelitian relevan sebelumnya bahwa soal belum memuat pengembangan keterampilan abad ke-21 secara keseluruhan (Yuniar, 2020) dan soal bermuatan HOTS masih minim termuat pada naskah soal (Marliana, 2020). Dalam penelitian ini permasalahan juga terdapat pada kesenjangan persebaran indikator kompetensi keterampilan, jika indikator tersebut dijadikan penilaian dalam naskah soal dan terjadi kesenjangan dalam persebaran jumlah soal tentunya akan berpengaruh pada proses evaluasi, maka dari itu kegiatan analisis butir soal sebelum diujikan sangatlah bermanfaat dan penting untuk dilakukan supaya meningkatkan mutu dari soal yang sudah ditulis (Waty, 2017). Banyak manfaat yang didapatkan bila kegiatan analisis butir soal dilakukan diantaranya menemukan soal cacat dan soal yang tidak berfungsi dengan baik, meningkatkan kualitas butir soal, meningkatkan validitas soal dan reliabilitas, merevisi soal yang tidak sesuai dengan materi yang diajarkan (Fitrianawati, 2015). Alangkah lebih baiknya bila muatan kompetensi keterampilan yang ingin diujikan melalui butir soal seimbang jumlahnya dan menggunakan indikator analisis yang dapat mengukur kemampuan peserta didik sesuai dengan keterampilan yang dibutuhkan saat ini, sebagaimana keterampilan yang digunakan pada analisis soal penelitian ini yaitu keterampilan berpikir kritis (critical thinking) dan keterampilan komunikasi tertulis (communication skills) pada butir soal, keterampilan tersebut termasuk kedalam keterampilan abad ke-21 yang bertujuan untuk menghasilkan peserta didik sebagai generasi muda yang memiliki kompetensi utama, kompetensi tersebut diantaranya kompetensi berpikir, kompetensi bekerja, kompetensi berkehidupan dan kompetensi menguasai alat bekerja (Abidin, 2015). 


\section{SIMPULAN}

Berdasarkan temuan dan pembahasan dari hasil analisis pada naskah soal Penilaian Akhir Semester mata pelajaran IPS kelas 5 tahun ajaran 2020/2021 dapat diambil kesimpulan untuk menjawab rumusan masalah dalam penelitian, diantaranya sebagai berikut: (1) Kualitas kesesuaian butir soal dengan kompetensi dasar dan materi IPS pada naskah soal Penilaian Akhir Semester mata pelajaran IPS kelas 5 pada tahun ajaran 2020/2021 sudah baik. Dari keseluruhan 35 soal terdapat 33 soal sesuai dengan kompetensi dasar dan materi IPS yang dibelajarkan pada semester ganjil. Persebaran muatan kompetensi dasar dan materi IPS pada butir soal belum merata, terbukti dari jumlah butir soal untuk setiap muatannya memiliki angka selisih yang cukup banyak. Muatan kompetensi dasar 3.1 dan materi karakteristik geografis Indonesia sebanyak 10 butir soal, kompetensi dasar 3.2 dan materi bentuk identifikasi manusia dengan lingkungan sebanyak 14 butir soal, kompetensi dasar 3.3 dan materi peran ekonomi dalam upaya menyejahterakan kehidupan masyarakat di bidang sosial dan budaya sebanyak 9 soal; (2) Keterampilan berpikir kritis (critical thinking) pada butir soal Penilaian Akhir Semester yang ditinjau dari lima aspek indikator memiliki tingkat muatan yang berbeda setiap aspeknya. Pada aspek memberikan penjelasan sederhana (elementary clasification) sebanyak 21 butir soal dengan pesersentase $60 \%$ berkategori sedang, soal dengan aspek membangun keterampilan dasar (basic support) sebanyak 17 butir soal dengan persentase $48.5 \%$ berkategori sedang, aspek menyimpulkan (inference) sebanyak 24 butir soal dengan persentase $68.5 \%$ berkategori banyak, sedangkan aspek membuat penjelasan lanjut (advanced clarification) sebanyak 9 butir soal dengan persentase $25.7 \%$ berkategori sedikit, dan soal dengan aspek strategi dan taktik (strategies and tactics) sebanyak 20 butir soal dengan persentase $57.1 \%$ berkategori sedang; (3) Keterampilan komunikasi tertulis (communication skills) yang tercipta pada naskah soal Penilaian Akhir Semester ditinjau dari indikator materi, konstruksi dan bahasa belum merata dan terdapat butir soal yang belum memuat indikator. Keterampilan komunikasi tertulis pada indikator materi termuat pada 10 butir soal pilihan ganda dan 9 butir soal uraian. Sedangkan keterampilan komunikasi tertulis indikator konstruksi termuat pada 15 butir soal pilihan ganda dan 7 soal uraian, dan untuk indikator bahasa termuat pada 11 butir soal pilihan ganda dan 14 butir soal uraian. 


\section{DAFTAR PUSTAKA}

Abidin, Y. (2015). Pembelajaran Multiliterasi Sebuah Jawaban atas Tantangan Pendidikan Abad Ke-21 dalam Konteks Keindonesiaan (ke-1). PT. Refika Aditama.

Arifin, Z. (2016). Evaluasi Pembelajaran Prinsip, Teknik dan Prosedur. PT. Remaja Rosdakarya.

Effendi, R. (2012). Perspektif dan tujuan pendidikan IPS. In Pengembangan Pendidikan IPS (pp. 1-41).

Fitrianawati, M. (2015). Peran analisis butir soal guna meningkatkan kualitas butir soal, kompetensi guru dan hasil belajar peserta didik. Prosiding Seminar Nasional Pendidikan PGSD UMS \& HDPGSDI Wilayah Jawa, 5(3), 282-295.

Isbandiyah, S., \& Sanusi, A. (2019). Modul Penyusunan Soal Keterampilan Tingkat Tinggi (High Order Thinking Skills) Biologi. Kemendikbud.

Jupriyanto. (2018). Kemampuan berpikir kritis siswa dalam pembelajaran ilmu pengetahuan alam kelas IV. Jurnal Ilmiah Pendidikan Dasar, 5(2), 105. https://doi.org/10.30659/pendas.5.2.105-111

Kurniawati, K. (2021). Analisis validitas isi instrumen tes berpikir kritis IPS kelas V SD Kota Yogyakarta. Pelita: Jurnal Penelitian Dan Karya Ilmiah, 21(1), 130-140.

Marliana, N. A. (2020). ANALISIS SOAL TES BIDANG STUDI IPS DITINJAU DARI DIMENSI HOTS: Buku siswa kelas IV sekolah dasar. Universitas Pendidikan Indonesia.

Moleong, L. J. (2017). Metode Penelitian Kualitatif. Remaja Rosdakarya.

Mukhtar. (2013). Metode Prakits Penelitian Deskriptif Kualitatif. REFERENSI (GP Press Group).

Mutiani. (2017). IPS dan pendidikan lingkungan: Urgensi pengembangan sikap kesadaran lingkungan peserta didik. SOSIO-DIDAKTIKA: Social Science Education Journal, 4(1), 45-53. https://doi.org/10.15408/sd.v4i1.5718

Nuriyah, N. (2014). Evaluasi pembelajaran: Sebuah kajian teori. Jurnal Edueksos, 3(1), 73-86.

Pengelola Web Kemendikbud. (2017). Pendidikan Karakter Dorong Tumbuhnya Kompetensi Siswa Abad 21. Blog Kemendikbud. https://www.kemdikbud.go.id/main/blog/2017/06/pendidikan-karakterdorong-tumbuhnya-kompetensi-siswa-abad-21

Priyanti, R. (2013). Pembelajaran inovatif abad 21. Prosiding Seminar Nasional Teknologi Pendidikan Pascasarjana UNIMED, 3(vii), 482-505.

Santika, R. (2019). Analisis Butir Soal Ujian Sekolah Mata Pelajaran IPS SD Negeri Dabin II Kecamatan Margadana Kota Tegal Tahun Ajaran 2018/2019. Universitas Negeri Semarang.

Sukardi. (2016). Metodologi Penelitian Pendidikan. PT. Bumi Aksara.

Uno, H. B., \& Lamatenggono, N. (2016). Landasan Pendidikan. PT. Bumi Aksara.

Valen, A. (2020). Analisis Pemahaman Guru Dan Kemampuan Menyusun Soal Mid Semester Mata Pelajaran IPS Sekolah Dasar. Jurnal Basicedu, 4(4), 1084-1097. https://doi.org/10.31004/basicedu.v4i4.501

Wandi, M. A. (2020). ANALISIS SOAL TES MATERI IPS PADA BUKU SISWA KELAS V DITINJAU DARI PENGEMBANGAN HOTS: Penelitian Deskriptif Kualitatif terhadap Soal Tes Buku Siswa Kelas V Sekolah Dasar. Universitas Pendidikan Indonesia.

Waty, E. R. K. (2017). Menelaah Kualitas Soal Ujian Sekolah Buatan Guru Pada Pencapaian Kelulusan Siswa. Jurnal Pendidikan Dan Pemberdayaan Masyarakat, 4(2), 11-17.

Yuniar, J. (2020). Analisis Soal Penilaian Akhir Tahun (PAT) Kelas V Sekolah Dasar 
Ditinjau dari Dimensi HOTS (Higher Order Thinking Skills). Universitas Pendidikan Indonesia.

Conflict of Interest Statement: The authors declare that the research was conducted in the absence of any commercial or financial relationships that could be constructed as a potential conflict of interest. 